\title{
112 \\ Current distribution and abundance of slender lorises (Loris tardigradus and L. Iydekkerianus) in Sri Lanka
}

\author{
S N Gamage', D K Weerakoon² and A Gunawardena' \\ 'Department of Animal Science, University of Ruhuna, Sri Lanka \\ Department of Zoology, University of Colombo, Sri Lanka.
}

Two species of slender lorises are currently recognized in Sri Lanka. They are Sri Lanka red slender loris (Loris tardigradus) and Grey slender loris (L. lydekkerianus), with four currently recognized sub-species; viz. Western red slender loris (L. t. tardigradus), Montane slender loris ( $L$. $t$. nycticeboides), Northern grey slender loris (L.l.nordicus), and Highland slender loris (L. l. grandis). The objective of this survey was to map the distribution and estimate the abundance of lorises in Sri Lanka. The study was initiated in 2002 and continues to date. Thus far forty-five sites across all of the ecological zones have been surveyed covering approximately $400 \mathrm{~km}^{2}$. In six of these sites, lorises were not recorded. Of the other 39 sites, 223 sightings of slender loris (L. t. tardigradus $(\mathrm{n}=86), L$. t. nycticeboides $(\mathrm{n}=3)$, L. I. nordicus $(\mathrm{n}=122)$, and L. l. grandis $(\mathrm{n}=12)$. Abundance estimates, base on sightings of animals $\mathrm{km}^{-1}$, were: L. t. tardigradus (0.5-8), L. t. nycticeboides (0.03), L. l. nordicus $(0.7-13)$, and $L$. l. grandis $(0.3-4)$ were recorded. The abundance of lorises varied in different habitat types with the highest abundance of lorises occurring in the dry zone monsoon forests. The least abundance of lorises was recorded in the cloud forest.

$\underline{113}$

\section{Preliminary study on herpetofaunal diversity of Nilgala forest area in Monaragala district, Sri Lanka}

\author{
D M S S Karunarathna, A A T Amarasinghe, U T I Abeywardena, M D C Asela and D G R \\ Sirimanna \\ The Young Zoologists' Association of Sri Lanka, National Zoological Gardens, Dehiwala, Sri Lanka.
}

Nilgala Forest Area (NFA) is one of the largest and important forest area in Monaragala District, Uva Province. It contain 12,432 hectares and lies within $7^{\circ} 08^{\circ}-7^{\circ} 14^{\circ} \mathrm{NL}$ and $81^{\circ} 16^{\circ}-81^{\circ} 20^{\circ} \mathrm{EL}$. Its elevation range between $200 \mathrm{~m}$ to $700 \mathrm{~m}$ within the Irindahela, Hangale, Yakun hela (highest point 700 m), Hamapola, Badangamuwa, Keenagoda, Makada, Karadugala, Kukulagoda, Ewalahela, Gorikkada hills. The mean annual rainfall varies between where the average annual rainfall $1500 \mathrm{~mm}-2000 \mathrm{~mm}$ (rain during northeast monsoon), while the mean annual temperature of the area is $28{ }^{\circ} \mathrm{C}-31^{\circ} \mathrm{C}$. The vegetation comprised with lowland tropical moist semi evergreen forest and savannah forest, home gardens and small patch paddy cultivations. The dominant tree species are Aralu (Terminalia chebula), Bulu (Terminalia bellirica) and Nelli (Phyllanthus emblica). Other than biodiversity, Nilgala is rich of archaeological monuments, such as prehistoric, proto-historic and historical Buddhist monasteries.

During the two-year study period, total number of 70 reptile species were and 19 amphibian species recorded. Reptiles include 44 genera of 17 families and $20(28.5 \%)$ endemic species. Amphibian fauna contain 13 genera including 4 families and $6(31.5 \%)$ endemic species. $41.4 \%$ (29) of reptiles and $26.3 \%$ (5) of Amphibians listed as 'Nationally Threatened' in the 1999 IUCN National threatened list. Out of 70 species $38(54.2 \%$ ) are Serpentoid reptiles (11 endemics) and $32(45.7 \%)$ species are of Tetrapod reptiles ( 9 endemics). Among the recorded species, 11 Serpentoid, 3 Tetrapod, and 2 amphibians have not been recorded by previous workers. Furthermore seven unidentified species were also recorded during the survey, which probably include new amphibian species belonging to genus Nannophrys. Human activities such as man-made fire, illegal logging, extensive use of chemicals for agriculture, forest clearing for chena cultivation and road kills were identified as a main threat for the natural habitats as well as faunal species. 